\title{
New aspects of the photodegradation of iron(III) citrate: spectroscopic studies and plant-related factors
}

\author{
Maria Gracheva ${ }^{1,2} \circledast$ - Zoltán Homonnay ${ }^{1} \cdot$ Amarjeet Sing $^{3,4} \cdot$ Ferenc Fodor $^{3} \cdot$ Vanda B. Marosi ${ }^{5} \cdot$ Ádám Solti $^{3}$. \\ Krisztina Kovács ${ }^{1}$
}

Received: 8 December 2021 / Accepted: 7 February 2022 / Published online: 23 February 2022

(c) The Author(s) 2022

\begin{abstract}
Iron $(\mathrm{Fe})$ is an essential cofactor for all livings. Although $\mathrm{Fe}$ membrane transport mechanisms often utilize $\mathrm{Fe}^{\mathrm{II}}$, uncoordinated or deliberated ferrous ions can initiate Fenton reactions. Fe ${ }^{\mathrm{III}}$ citrate complexes are among the most important complexed forms of $\mathrm{Fe}^{\mathrm{III}}$ especially in plants that, indeed, can undergo photoreduction. Since leaves as photosynthetic organs of higher plants are generally exposed to illumination in daytime, photoreaction of ferric species may have biological relevance in iron metabolism, the relevance of which is poorly understood. In present work Fe $\mathrm{III}^{\mathrm{III}}$ citrate transformation during the photodegradation in solution and after foliar application on leaves was studied by Mössbauer analysis directly. To obtain irradiation time dependence of the speciation of iron in solutions, four model solutions of different $\mathrm{pH}$ values $(1.5,3.3,5.5$, and 7.0) with Fe to citrate molar ratio 1:1.1 were exposed to light. Highly acidic conditions led to a complete reduction of Fe together with the formation of $\mathrm{Fe}^{\mathrm{II}}$ citrate and hexaaqua complexes in equal concentration. At higher $\mathrm{pH}$, the only product of the photodegradation was $\mathrm{Fe}^{\mathrm{II}}$ citrate, which was later reoxidized and polymerized, resulting in the formation of polynuclear stable ferric compound. To test biological relevance, leaves of cabbage were treated with $\mathrm{Fe}^{\mathrm{III}}$ citrate solution. X-ray fluorescence imaging indicated the accumulation of $\mathrm{Fe}$ in the treated leaf parts. Mössbauer analysis revealed the presence of several ferric species incorporated into the biological structure. The Fe speciation observed should be considered in biological systems where $\mathrm{Fe}^{\mathrm{III}}$ citrate has a ubiquitous role in $\mathrm{Fe}$ acquisition and homeostasis.
\end{abstract}

Maria Gracheva

gracheva@student.elte.hu

1 Institute of Chemistry, ELTE Eötvös Loránd University, Pázmány Péter s. 1/A, Budapest 1117, Hungary

2 Hevesy György Doctoral School of Chemistry, ELTE Eötvös Loránd University, Pázmány Péter s. 1/A, Budapest 1117, Hungary

3 Department of Plant Physiology and Molecular Plant Biology, Institute of Biology, ELTE Eötvös Loránd University, Pázmány Péter s. 1/C, Budapest 1117, Hungary

4 Doctoral School of Biology, ELTE Eötvös Loránd University, Pázmány Péter s. 1/C, Budapest 1117, Hungary

5 Plant Genome and Systems Biology, Helmholtz Center Munich, German Research Center for Environmental Health (GmbH), Ingolstädter Landstr. 1, 85764 Neuherberg, Germany 


\section{Graphical abstract}

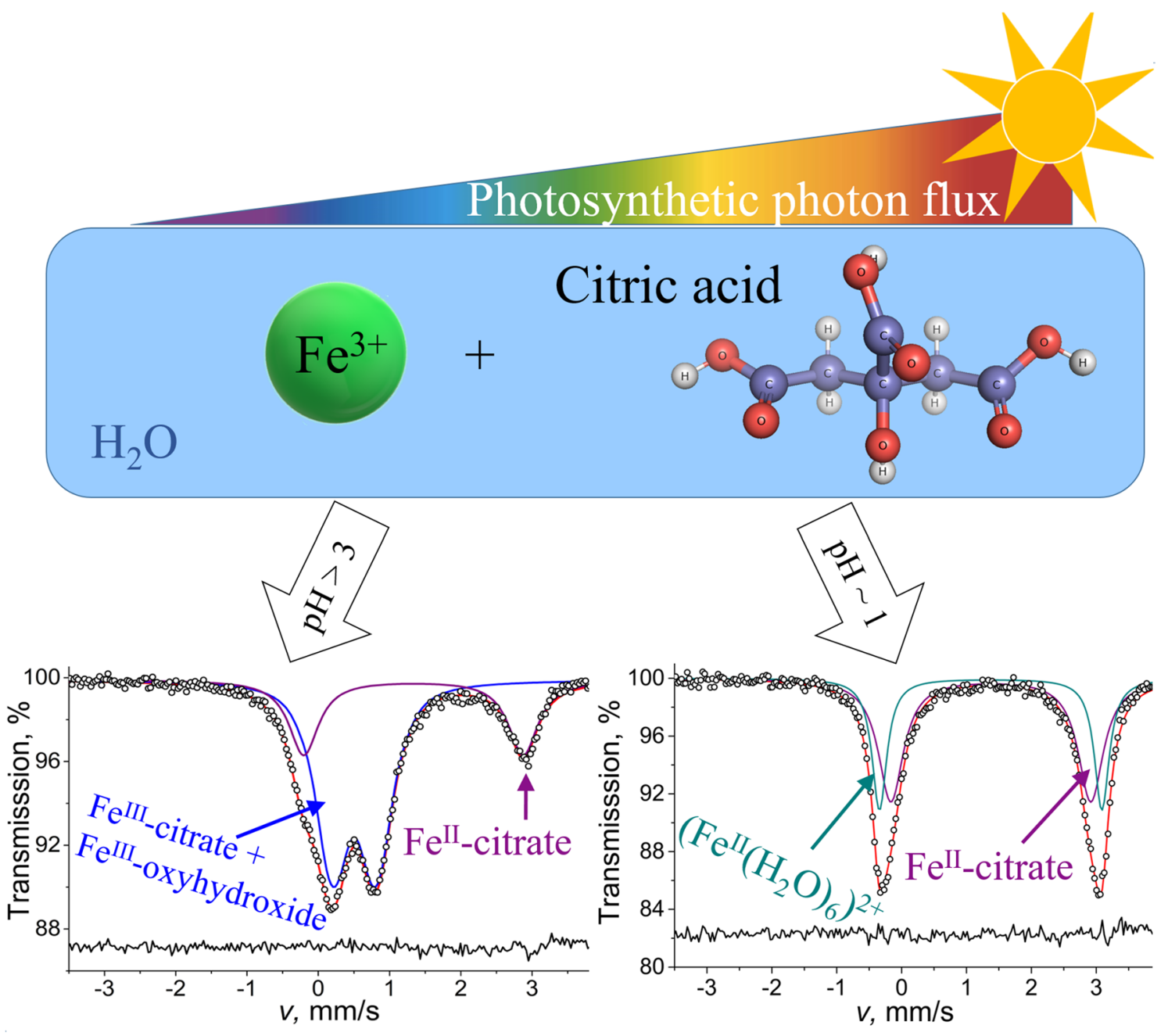

Keywords Iron citrate complex $\cdot$ Mössbauer spectroscopy $\cdot$ Photodegradation $\cdot$ Iron polymerization $\cdot$ Plant nutrition

\section{Introduction}

As mineral nutrient, iron $(\mathrm{Fe})$ is required in micromolar concentration for plant growth and development. Since Fe is involved in multiple cellular functions, disturbances in iron transport and metabolism processes lead to a series of malfunctions such as disrupted photosynthetic function, decreased growth and crop yield [1-3]. Decreased crop yield is one of the most important challenging factors of agriculture; therefore, $\mathrm{Fe}$ nutrition of plants is in the focus of investigations. Multilateral research programs [4] have demonstrated that foliar fertilization is an effective agronomic approach to attain desirable concentrations of micronutrients for human nutrition. Citrate being the major candidate for Fe complexation in the long distance transport is widely applied as a possible ligand in foliar treatment applications
$[5,6] . \mathrm{Fe}^{\mathrm{III}}$ citrate is a collective term for a large group of various carboxylate complexes containing ferric ions and citrate ligands at various degrees of protonation. Due to the affinity of citric acid to metal ions, it is secreted by plant roots and certain bacteria thus facilitating $\mathrm{Fe}$ mobilization from insoluble $\mathrm{Fe}$ pools of the medium. Citrate complexes also facilitate the transport of $\mathrm{Fe}$ through the cell membranes [7-9]. However, in contrast to the well-characterized Fe acquisition of roots, details of Fe metabolism in mesophyll cells are not entirely revealed. Mesophyll cells, chloroplasts and most likely mitochondria in the leaves operate as agents in reduction based Fe uptake. Reduction-based iron transport mechanism of plants requires Ferric Reductase Oxidase (FRO) family of ferric chelate reductase enzymes in various plant membranes [10]. The reduction-based iron transport is best characterized for chloroplasts that clearly 
prefer the utilization of $\mathrm{Fe}^{\mathrm{III}}$ citrate complexes in the uptake $[11,12]$. The reduction-based Fe acquisition of chloroplasts is driven by a reducing power generated in photosynthetic processes. Indeed, Arabidopsis fro 7 mutants that lack functioning chloroplast FRO enzymes were shown to be able to perform chloroplast Fe uptake where Fe photoreduction processes were also proposed to be present [13]. Since leaves are exposed to illumination during the diurnal periods, photoreactivity of Fe species should be considered to describe foliar Fe homeostasis. Despite its key biological relevance, the photochemical properties of $\mathrm{Fe}^{\mathrm{III}}$ citrate complexes in solutions remain unclear.

Light is known to promote $\mathrm{Fe}^{\mathrm{III}}$ reduction at the expense of oxidative decarboxylation of the carboxylate. The quantum yield and the final products highly depend on the $\mathrm{pH}$ of the solution, ligand-to-metal ratio and the type of the light source. Since the 1910s until now [14, 15], studies of ferric citrate photodegradation have been performed by means of different methods involving detection of the organic products of the carboxylate degradation. The organic intermediates were found to be acetonedicarboxylic acid (3-oxoglutaric acid) and acetoacetic acid, which further decay into acetone and carbon dioxide [16-18]. According to Feng et al. [19], the general reaction of $\mathrm{Fe}^{\mathrm{III}}$ citrate photodegradation can be represented as follows:

$$
\begin{aligned}
& \mathrm{C}(\mathrm{OH})(\mathrm{COOH})\left(\mathrm{CH}_{2} \mathrm{COOH}\right)_{2}+2 \mathrm{Fe}^{3+}+h v \\
& \rightarrow \mathrm{CH}_{3} \mathrm{COCH}_{3}+2 \mathrm{Fe}^{2+}+3 \mathrm{CO}_{2}+2 \mathrm{H}^{+} .
\end{aligned}
$$

Further reaction can take place on different routes. Some authors claim reoxidation of $\mathrm{Fe}^{2+}[18,20,21]$ back to the ferric form by reaction with $\mathrm{O}_{2}{ }^{--}, \mathrm{HO}_{2}$ or $\mathrm{H}_{2} \mathrm{O}_{2}$ (Fenton reaction) produced from the unimolecular or bimolecular decay of organic peroxyl radicals [22]. The composition of the final products of reoxidation remains questionable. In most of the works, the coordination of ferric ions in the final state is not specified, while others suggest cyclic formation of the $\mathrm{Fe}^{\mathrm{III}}$ citrate complex [21]. However, most of these studies are devoted to determining the quantum yield of $\mathrm{HO}$. radical formation $[14,23,24]$. The only characterization of the $\mathrm{Fe}^{\mathrm{III}}$ form obtained after total photoreduction of $\mathrm{Fe}^{\mathrm{III}}$ citrate solution was performed by Dodge and Francis [18] using X-ray diffraction analysis of the precipitate, which was identified as ferrihydrite. However, the analysis included filtering of the solution which could also affect the chemical form of iron.

The way of formation and the stability of ferrous complexes are still under debate. Some studies suggest a nearly complete transformation of $\mathrm{Fe}^{\mathrm{III}}$ to $\mathrm{Fe}^{\mathrm{II}}$ and the formation of a stable long-lived ferrous complex [16, 25, 26]. This contradiction might occur because the measurement of $\mathrm{Fe}^{\mathrm{II}}$ was performed by adding $o$-phenanthroline [14, 17, 21, 22, 25], bathophenanthroline disulfonate (BPDS) [26] or ferrozine
[27] as $\mathrm{Fe}^{\mathrm{II}}$ indicator reagents. However, addition of an agent with strong complexation power to $\mathrm{Fe}^{\mathrm{II}}$ can influence the chemical equilibrium of the reaction (1) by removing the reduced product from the system. Moreover, the agent may also change the $\mathrm{pH}$ of the solution. Furthermore, the spectrophotometric determination of $\mathrm{Fe}^{\mathrm{II}}$ concentration requires measuring absorption of light, which can be considered as additional irradiation of the sample resulting in photoreduction during the measurement. Therefore, these results may not give fully comprehensive information on the $\mathrm{Fe}^{\mathrm{II}}$ species formed during photodegradation of $\mathrm{Fe}^{\mathrm{III}}$ citrate and the $\mathrm{Fe}^{\mathrm{II}}$ concentration can be also influenced by the experimental factors.

For this reason, the aim of the present work was a direct investigation of the photodegradation of $\mathrm{Fe}^{\mathrm{III}}$ citrate solution by applying ${ }^{57} \mathrm{Fe}$ Mössbauer spectroscopy, which is a powerful tool to investigate electronic and magnetic properties of $\mathrm{Fe}$ compounds and their transformation [28-30]. Although the Mössbauer effect can occur only in solids, it was shown to be an effective way to study the chemical structures of solutions by freezing them. In the case of rapid cooling applied, the coordination and bonding conditions of the dissolved species in the solution are preserved. Therefore, such method gives reliable information on the oxidation state and chemical form of $\mathrm{Fe}$ in the original solution [30-32]. Despite not being a routine biological technique, Mössbauer spectroscopy showed a significant analytical potential in investigating a wide range of biological objects (from biocomplexes and biomacromolecules to supramolecular structures, cells, tissues, and organisms) [33-35]. In the present work, biological relevance of the photodegradation was also studied with the same method in the model plant after foliar treatments with $\mathrm{Fe}^{\mathrm{III}}$ citrate solution.

\section{Materials and methods}

\subsection{Preparation}

Stock solution of enriched ferric chloride ${ }^{57} \mathrm{FeCl}_{3}$ (enriched in ${ }^{57} \mathrm{Fe}$, ca. $90 \%$ ) was prepared by dissolving metallic iron ${ }^{57} \mathrm{Fe}$ foil in $\mathrm{HCl}$, additionally $\mathrm{H}_{2} \mathrm{O}_{2}$ was used to ensure the $\mathrm{Fe}^{\mathrm{III}}$ oxidation state. Stock solution of ferrous sulfate ${ }^{57} \mathrm{FeSO}_{4}$ (enriched in ${ }^{57} \mathrm{Fe}$, ca. 90\%) was prepared by dissolving metallic iron ${ }^{57} \mathrm{Fe}$ foil in $\mathrm{H}_{2} \mathrm{SO}_{4}$ with the excess of metallic iron to ensure the $\mathrm{Fe}^{\mathrm{II}}$ oxidation state. Before further preparations, both stock solutions were analyzed by means of Mössbauer spectroscopy. Citric acid monohydrate $>99.7 \%$ purity (VWR Chemicals, BDH Prolabo, Belgium, CAS 77-92-9) was used as citrate source.

To investigate the photoreduction of ferric ions induced by citric acid, four samples with $\mathrm{Fe}^{\mathrm{III}}$ to citrate molar ratios 1:1.1 were prepared at different $\mathrm{pH}$ values chosen according 
to the literature data and physiological relevance. Taking into account the $\mathrm{p} K_{\mathrm{a}}$ values of the citric acid deprotonation $\left(\mathrm{p} K_{1}=3.13, \mathrm{p} K_{2}=4.76\right.$ and $\mathrm{p} K_{3}=6.40$ and that for the hydroxyl proton is $\mathrm{p} K_{4}=14.4$ ) [36], the selected $\mathrm{pH}$ values below represent decreasing protonation state as well as increasing complexation power of citric acid.

(1) The very acidic $\mathrm{pH} 1.5$ was chosen as a model system for $\mathrm{Fe}^{\mathrm{III}}$ and citric acid where no complex formation is suggested [37, 38]. At this $\mathrm{pH}$, photoreduction has been observed by [20], but in contrast, other studies have reported no transformation [17];

(2) $\mathrm{pH} 3.3$ was chosen for the highest quantum yield reported for photoreduction of $\mathrm{Fe}^{\mathrm{III}}$ to $\mathrm{Fe}^{\mathrm{II}}[17,20]$;

(3) The slightly acidic pH 5.5 was chosen since it is close to the conditions of the plant xylem sap [39] which is responsible for the transport of $\mathrm{Fe}$ in plants;

(4) The neutral pH 7.0 was chosen since it is close to the conditions of the cytoplasm of plant cells [12].

During all preparation process, the $\mathrm{pH}$ of the solutions was kept in the investigated range with appropriate portions of $\mathrm{KOH}$ solutions of various concentrations. The exposition of the solutions to light during preparation was negligible, and the solutions were kept in dark before investigation. The $\mathrm{pH}$ was checked again after overnight equilibration right before the measurements. The final $\mathrm{Fe}$ concentration of all solutions was $0.03 \mathrm{M}$.

To determine the Mössbauer parameters of the $\mathrm{Fe}^{\mathrm{II}}$ citrate complex, ${ }^{57} \mathrm{FeSO}_{4}$ was mixed with citric acid at 1:1.1 molar ratio. After the measurement at acidic conditions, $\mathrm{pH}$ of the solution was adjusted to 6 using aqueous $\mathrm{KOH}$ solution.

\subsection{Illumination}

As for illumination treatment, $\mathrm{Fe}^{\mathrm{III}}$ citrate-containing samples were placed into quartz cuvettes (spectral range 200-2500 nm, Hellma Suprasil ${ }^{\circledR}$ ) and were kept under illumination $\left[120 \mu \mathrm{mol}\right.$ photons $\mathrm{m}^{-2} \mathrm{~s}^{-1}$ photosynthetic photon flux density (PPFD)] from Master HPI-T Plus 400 W/645 E40 mercury lamps (Philips). These conditions correspond to the light conditions of the growth chamber applied in cultivating the plant material $[11,12]$.

\subsection{Cultivation, treatment and characterization of plant model}

Cabbage (Brassica oleracea L. convar. capitata var. alba cv. Júniusi Óriás) was used as a model plant. After germination, plants were cultivated on quarter-strength Hoagland's nutrient solution $\left(1.25 \mathrm{mM} \mathrm{KNO}_{3} ; 1.25 \mathrm{mM} \mathrm{Ca}\left(\mathrm{NO}_{3}\right)_{2}\right.$; $0.5 \mathrm{mM} \mathrm{MgSO} \mathrm{M}_{4} ; 0.25 \mathrm{mM} \mathrm{KH} \mathrm{PO}_{4} ; 11.6 \mu \mathrm{M} \mathrm{H}_{3} \mathrm{BO}_{3}$; $4.5 \mu \mathrm{M} \mathrm{MnCl}_{2} \times 4 \mathrm{H}_{2} \mathrm{O} ; 0.19 \mu \mathrm{M} \mathrm{ZnSO}_{4} \times 7 \mathrm{H}_{2} \mathrm{O} ; 0.12 \mu \mathrm{M}$
$\left.\mathrm{Na}_{2} \mathrm{MoO}_{4} \times 2 \mathrm{H}_{2} \mathrm{O} ; 0.08 \mu \mathrm{M} \mathrm{CuSO} \mathrm{C}_{4} \times 5 \mathrm{H}_{2} \mathrm{O}\right]$ with an iron source of $10 \mu \mathrm{M}$ Fe ${ }^{\mathrm{III}}$-EDTA (natural iron, Sigma-Aldrich) in 1.5-1 plastic buckets. To induce Fe deficiency, the plants were cultivated on an Fe-free medium after the pre-cultivation until reaching the four-leaf stage. Environmental parameters were: $14 \mathrm{~h} 120 \mu \mathrm{mol}$ photons $\mathrm{m}^{-2} \mathrm{~s}^{-1}$ PPFD illumination/10-h dark periods; $70 / 85 \%$ relative humidity; $22 / 24{ }^{\circ} \mathrm{C}$.

${ }^{57} \mathrm{Fe}{ }^{\mathrm{III}}$ citrate solution was prepared at $\mathrm{pH} 5.5$ as described above and was diluted to the final $\mathrm{Fe}$ concentration of $5 \mathrm{mM}$. To ensure the even distribution of the applied foliar treatment on the leaf surface, $0.1 \%$ of Nonit $\left(566 \mathrm{~g} \mathrm{l}^{-1}\right.$ dioctylsulfosuccinate Na salt; Agrokémia Sellye Zrt., Hungary) was applied as surfactant. Leaves grown under the Fe-deficient conditions were treated with $250 \mu$ l solution by gently dispersing the solution both on the adaxial and on the abaxial surface with a brush. Two treatments were applied on the same leaves with an interval of 3 days. One week after the first foliar treatment, leaves were collected. A part of the samples was immediately frozen in liquid nitrogen, whereas the second part of the leaf samples was washed first in $0.1 \%$ Nonit, then in deionized water and frozen in liquid nitrogen thereafter.

SPAD index and chlorophyll- $a$ fluorescence induction was applied for physiological characterization of the status of the plant material using SPAD meter (Minolta SPAD502) and PAM 101-102-103 Chlorophyll Fluorometer (Walz, Effeltrich, Germany), respectively. Prior to the chlorophyll$a$ fluorescence induction measurement, leaves were darkadapted for $30 \mathrm{~min} . F_{0}$ was determined by switching on the measuring light $\left(1.6 \mathrm{kHz}\right.$, less than $1 \mu \mathrm{mol} \mathrm{m}{ }^{-2} \mathrm{~s}^{-1}$ PPFD) after $3 \mathrm{~s}$ far-red illumination. $F_{\mathrm{m}}$ was measured by applying a $0.7 \mathrm{~s}$ pulse of white light $\left(3500 \mu \mathrm{mol}\right.$ photon $\mathrm{m}^{-2} \mathrm{~s}^{-1}$ PPFD, light source: KL 1500 electronic, Schott, Mainz, Germany). From these data, the maximal quantum efficiency of photosystem II reaction centers $\left(F_{\mathrm{v}} / F_{\mathrm{m}}=\left(F_{\mathrm{m}}-F_{0}\right) / F_{\mathrm{m}}\right)$ was calculated [40].

\subsection{X-ray fluorescence imaging}

Leaves of Fe deficient cabbage plants were subjected to partial foliar treatment where either the basal part, or the right half of the leaf blade was treated with ${ }^{57} \mathrm{Fe}^{\mathrm{III}}$ citrate solution as described before (Suppl. Fig. 1). One week later the first foliar treatment leaves were collected, washed and dried at $60{ }^{\circ} \mathrm{C}$ under press ensuring smooth surface of the leaf blade. X-ray fluorescence (XRF) imaging was performed by XGT-7200 V (Horiba, Japan) with Rh K $\alpha$ radiation. The sample was set in vacuum at room temperature. Acceleration voltage and current of $50 \mathrm{kV}$ and $1 \mathrm{~mA}$, respectively, and $\mathrm{X}$-ray guide tube of $100 \mu \mathrm{m}$ were applied. Mapping areas of $15.36 \times 15.36 \mathrm{~mm}$ were subjected to analysis with $1000 \mathrm{~s}$ survey time per frame, collecting the data 5 times per pixel. 


\subsection{Mössbauer spectroscopy}

After exposure to light, the solutions were quickly frozen on the surface of a metal slab soaked in liquid nitrogen and kept in a liquid nitrogen bath type cryostat. To reveal the valence state and the microenvironment of iron, ${ }^{57} \mathrm{Fe}$ Mössbauer spectroscopy measurements were performed on the frozen solutions and leaves at liquid nitrogen temperature ( $T=80 \mathrm{~K}$ ), using a conventional Mössbauer spectrometer (WissEl, Starnberg, Germany) operating in constant acceleration mode with ${ }^{57} \mathrm{Co}$ source in $\mathrm{Rh}$ matrix.

Spectra were evaluated with the assumption of Lorentzian line shape by standard computer-based statistical analysis methods that included fitting the experimental data using a least-squares minimization procedure with the help of the MOSSWINN program [41]. The parameters calculated for the spectral components correspond to hyperfine parameters of Mössbauer nuclei such as isomer shift $(\delta)$, quadrupole splitting $(\Delta)$, linewidth $(\Gamma)$ and partial resonant absorption areas. ${ }^{57} \mathrm{Fe}$ isomer shifts are given relative to $\alpha$-iron at room temperature.

\section{Results}

\subsection{Photodegradation studies of iron(III) + citric acid solutions}

For all investigated $\mathrm{pH}$ values, the initial solution had a visible clear yellow color, as expected for $\mathrm{Fe}^{\mathrm{III}}$ citrate system [16]. However, Mössbauer studies of the mixture of iron and citric acid at very low pH (Fig. 1) showed no ferric citrate complex formation. The spectra of the ${ }^{57} \mathrm{FeCl}_{3}$ stock solution and its mixture with citric acid were identical and represented a broad relaxation component typical for $\mathrm{Fe}^{\mathrm{III}}$ chloride solutions [42]. Its evaluation was performed using the model suggested and described earlier in [30]. The spectrum obtained after $2 \mathrm{~h}$ of irradiation showed significant difference from the initial one and exhibited the consequences of photodegradation. Approximately half of iron was reduced to divalent state. The parameters of the more intense and broad $\mathrm{Fe}^{\mathrm{II}}$ component $(\delta=1.37 \pm 0.02 \mathrm{~mm} / \mathrm{s}$, $\Delta=3.42 \pm 0.02 \mathrm{~mm} / \mathrm{s}$, linewidth $\Gamma=0.28 \pm 0.02 \mathrm{~mm} / \mathrm{s}$ ) were close to those reported for $\mathrm{Fe}^{\mathrm{II}}$ hexaaqua complex $\left(\mathrm{Fe}\left(\mathrm{H}_{2} \mathrm{O}\right)_{6}\right)^{2+}[30]$. Another $\mathrm{Fe}^{\mathrm{II}}$ subspectrum had slightly different value of isomer shift $(\delta=1.34 \pm 0.02 \mathrm{~mm} / \mathrm{s})$ but smaller quadrupole splitting $(\Delta=3.08 \pm 0.02 \mathrm{~mm} / \mathrm{s})$ and larger linewidth $(\Gamma=0.46 \pm 0.03 \mathrm{~mm} / \mathrm{s})$ and could be identified as $\mathrm{Fe}^{\mathrm{II}}$-organic ligand complex. The ligand could be citrate or one of the products of citrate photodegradation; however, it may be mentioned that none of the possible degradation products [18] are suggested to be able to coordinate $\mathrm{Fe}^{\mathrm{II}}$ as strong as the multidentate citric acid. During
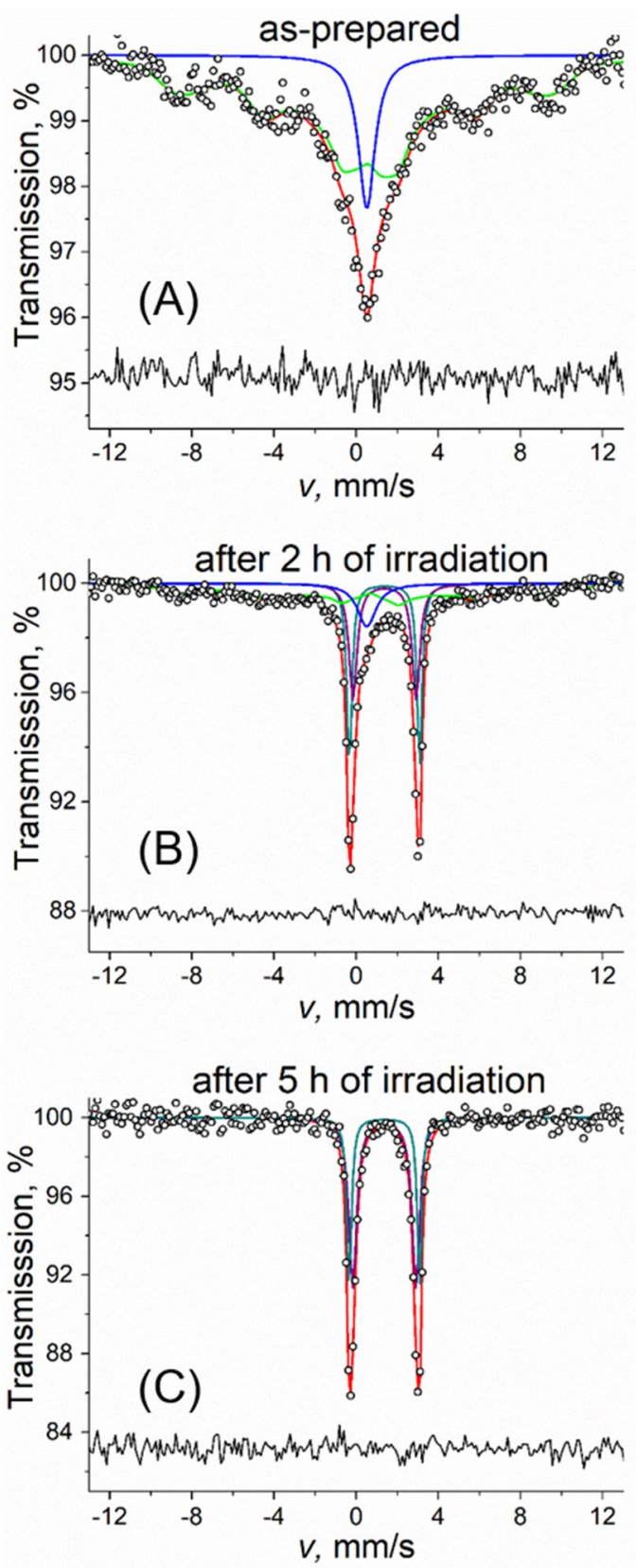

Fig. 1 Mössbauer spectra of the frozen iron(III) + citric acid solutions at $\mathrm{pH}$ 1.5: as-prepared from ${ }^{57} \mathrm{FeCl}_{3}(\mathbf{A})$ and after $2(\mathbf{B})$ and $5(\mathbf{C})$ hours of light irradiation

exposure to light, the solution gradually became paler and completely lost the color (as observed by visual inspection) after $5 \mathrm{~h}$ of irradiation. The Mössbauer spectrum of the frozen solution confirmed that by this time total photoreduction of the $\mathrm{Fe}^{\mathrm{III}}$ occurred. The ratio between the areas of the two different $\mathrm{Fe}^{\mathrm{II}}$ components was 1:1. According to the stoichiometry shown in Eq. (1), roughly half the citric acid content of the solution was consumed by the reduction process, so 
the $\mathrm{Fe}^{\mathrm{II}}$ product may be a citrato complex of $\mathrm{Fe}^{\mathrm{II}}$ with $1: 1$ metal to ligand ratio.

Spectra of the mixtures of $\mathrm{Fe}^{\mathrm{III}}$ and citric acid at $\mathrm{pH}>3$ (3.3, 5.5 and 7.0) were almost identical and consisted of a broad well-resolved doublet typical for $\mathrm{Fe}^{\mathrm{III}}$ citrate complex in aqueous solution [43] (Fig. 2). Within the margin of error, the isomer shift and the linewidth values in all cases were equal to $\delta=0.48 \pm 0.01 \mathrm{~mm} / \mathrm{s}, \Gamma=0.55 \pm 0.03 \mathrm{~mm} / \mathrm{s}$. The trend of larger quadrupole splitting at higher $\mathrm{pH}$ reported by Epstein et al. [43] was not convincingly observed: only a slight increase from $\Delta=0.63 \pm 0.01 \mathrm{~mm} / \mathrm{s}$ in the case $\mathrm{pH} 3.3$ and 5.5 to $\Delta=0.66 \pm 0.01 \mathrm{~mm} / \mathrm{s}$ at $\mathrm{pH} 7.0$ took place.

As the irradiation was applied, differences in the Mössbauer spectra were detectable. Already after $2 \mathrm{~h}$ of exposure to light, the effects of the photoreduction process could be seen. The $\mathrm{Fe}^{\mathrm{II}}$ component formed in all samples had the same parameters as the $\mathrm{Fe}^{\mathrm{II}}$-organic ligand complex described in the previous strongly acidic case. The ratio $\mathrm{Fe}^{\mathrm{II}} / \mathrm{Fe}^{\text {total }}$ was 0.29 for $\mathrm{pH} 3.3,0.08$ for $\mathrm{pH} 5.5$ and 0.04 for $\mathrm{pH} 7.0$, which was much smaller than at $\mathrm{pH} 1.5$ where after $2 \mathrm{~h}$ of exposure the half of the total Fe was already transformed into the divalent state. No detectable amount of $\mathrm{Fe}^{\mathrm{II}}$ hexaaqua complex was observed. No transformation of the $\mathrm{Fe}^{\mathrm{III}}$ citrate solutions stored in darkness occurred at any investigated $\mathrm{pH}$.

Based on Mössbauer evaluation, the $\mathrm{Fe}^{\mathrm{II}}$ production during photodegradation of $\mathrm{Fe}^{\mathrm{III}}$ citrate complexes at different $\mathrm{pH}$ was revealed and compared (Fig. 3). As the irradiation time increased from 2 to $5 \mathrm{~h}$, the relative amount of $\mathrm{Fe}^{\mathrm{II}}$ did not increase in the samples at $\mathrm{pH}>3$, in contrast to the sample at $\mathrm{pH} 1.5$, where all iron was photoreduced by that time. Due to its high plant biological relevance, $\mathrm{Fe}^{\mathrm{III}}$ citrate solution prepared at $\mathrm{pH} 5.5$ was investigated in a more detailed fashion. In total, seven time points were analyzed. At first, $\mathrm{Fe}^{\mathrm{II}}$ concentration increased much slower than it was observed in more acidic cases but faster than in the neutral solution and reached its maximum of approximately $3 \mathrm{mM}$ (11\% from the total iron amount) after $3.5 \mathrm{~h}$ of light irradiation (Fig. 2). Thereafter, the relative amount of $\mathrm{Fe}^{\mathrm{II}}$ started to decrease gradually.

Another observed difference was that in contrast to the very acidic case, the solutions at $\mathrm{pH}>3$ did not become transparent during the light exposure. The mixtures rather turned darker, more brownish and turbid, suggesting that there must be another process besides photoreduction of $\mathrm{Fe}$, and namely, hydrolysis took place in the cuvette. Moreover, in the Mössbauer spectra of samples irradiated at $\mathrm{pH}>3$, it was noticeable that the $\mathrm{Fe}^{\mathrm{III}}$ doublet was broader than it was in the as-prepared sample and its quadrupole splitting and linewidth slightly differed from the initial for ferric citrate (Fig. 2). As the irradiation time increased and the $\mathrm{Fe}^{\mathrm{III}}$ component broadened significantly, fitting with a single doublet became inappropriate and the application of a probability distribution of quadrupole splitting was required.
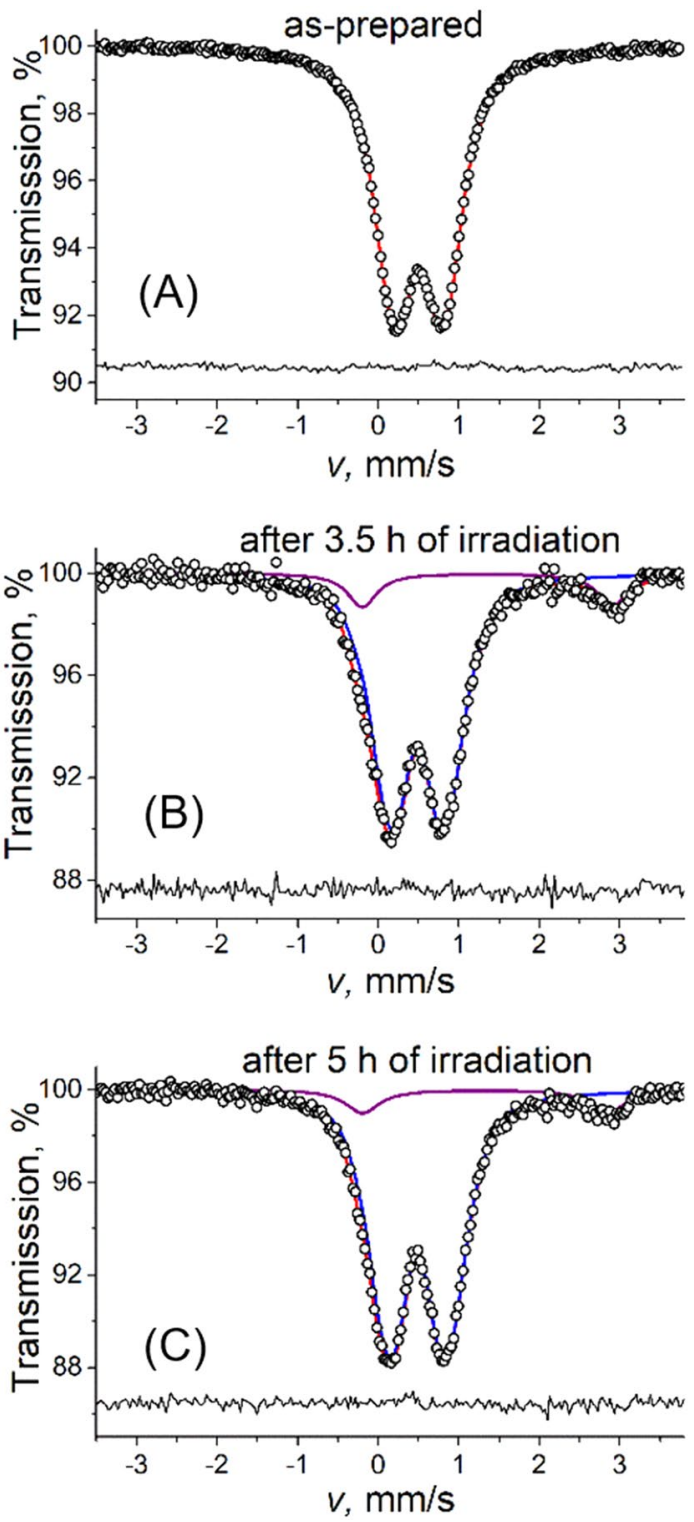

Fig. 2 Mössbauer spectra of the frozen iron(III) + citric acid solutions at pH 5.5: as-prepared from ${ }^{57} \mathrm{FeCl}_{3}(\mathbf{A})$ and after $3.5(\mathbf{B})$ and $5(\mathbf{C})$ hours of light irradiation

Figure 4A shows the spectrum of the frozen solution prepared at $\mathrm{pH} 5.5$ in its final state (after $32 \mathrm{~h}$ in the growth chamber). All newly formed $\mathrm{Fe}^{\mathrm{II}}$ observed earlier was reoxidized. The probability distribution of quadrupole splitting had isomer shift $\delta=0.48 \pm 0.01 \mathrm{~mm} / \mathrm{s}$ and linewidth $\Gamma=0.30 \pm 0.01 \mathrm{~mm} / \mathrm{s}$ and reached its maximum at the value $\Delta=0.77 \mathrm{~mm} / \mathrm{s}$. Such parameters were widely observed in the case of polynuclear Fe compounds formed via hydrolysis $[44,45]$. Since the microenvironments of Fe nuclei in this polymeric material differ from each other only slightly, the similarity of their hyperfine parameters makes it impossible to resolve different individual species. Based on the distribution shape, the sum of two doublets with different 


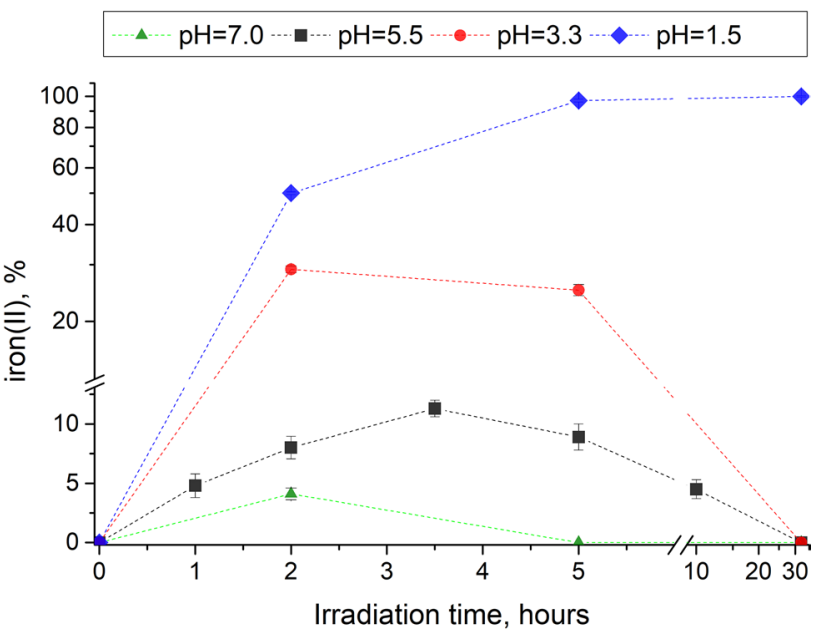

Fig. 3 Irradiation time dependence of iron(II) relative amount for different $\mathrm{pH}$, the dashed lines are guides to the eye

quadrupole splittings can be taken as the model representing the extremes of a continuum of doublets $[46,47]$. The spectrum of the solution obtained after a week of irradiation was identical to the described one and is not presented. This result suggests that the ferric complex formed is photochemically stable. The final spectra of the solutions prepared at $\mathrm{pH} 3.3$ and 7.0 and exposed to light for a time long enough for total transformation (approximately $32 \mathrm{~h}$ ) showed no significant difference compared to the one obtained for pH5.5 suggesting that the same process occurred in all three samples.

\subsection{Studies of iron(II) + citric acid solutions}

To identify $\mathrm{Fe}^{\mathrm{II}}$-organic ligand complex observed after photoreduction, a mixture of ${ }^{57} \mathrm{FeSO}_{4}$ and citric acid was measured as prepared $(\mathrm{pH} 1.0)$ and after rising the $\mathrm{pH}$ to approximately 6 . The spectrum of the acidic $\mathrm{Fe}^{\mathrm{II}}+$ citric acid solution (Fig. 5A) was not different from the spectrum of the initial stock solution of ${ }^{57} \mathrm{FeSO}_{4}$ and contained two doublets: one corresponding to $\mathrm{Fe}^{\mathrm{II}}$ hexaaqua complex $(\delta=1.39 \pm 0.01 \mathrm{~mm} / \mathrm{s}$, $\Delta=3.41 \pm 0.01 \mathrm{~mm} / \mathrm{s}, \Gamma=0.30 \pm 0.02 \mathrm{~mm} / \mathrm{s}$ ) with relative area of $92 \%$ and the minor component corresponding to $\mathrm{Fe}^{\mathrm{III}}(\delta=0.31 \pm 0.04 \mathrm{~mm} / \mathrm{s}, \Delta=0.36 \pm 0.06 \mathrm{~mm} / \mathrm{s}$, $\Gamma=0.51 \pm 0.12 \mathrm{~mm} / \mathrm{s}$ ) caused by oxidation on air during storage of the stock solution. After rising the $\mathrm{pH}$, both doublets slightly changed (Fig. 5B). The relative area of $\mathrm{Fe}^{\mathrm{III}}$ doublet increased to $49.5 \pm 0.1 \%$ due to fast oxidation of $\mathrm{Fe}^{\mathrm{II}}$ at higher $\mathrm{pH}$, while its parameters became identical to those observed earlier for $\mathrm{Fe}^{\mathrm{III}}$ citrate. The hyperfine parameters of the $\mathrm{Fe}^{\mathrm{II}}$ doublet were $\delta=1.32 \pm 0.02 \mathrm{~mm} / \mathrm{s}$, $\Delta=3.08 \pm 0.01 \mathrm{~mm} / \mathrm{s}, \Gamma=0.45 \pm 0.01 \mathrm{~mm} / \mathrm{s}$, suggesting the formation of $\mathrm{Fe}^{\mathrm{II}}$ citrate complex in the solution.

\subsection{Iron species in leaves after foliar treatment}

The efficiency of the foliar treatment of iron deficient cabbage plants with iron(III)-citrate was shown by the recovery of the iron deficiency induced chlorosis symptoms such as inhibited accumulation of chlorophylls and lowered maximal quantum efficiency of photosystem II reaction centers $\left(F_{\mathrm{v}} / F_{\mathrm{m}}\right)$ (Fig. 6). Although 1-week time was not enough for a total recovery of the SPAD index of treated leaves to the level of the iron sufficient control plants, $F_{\mathrm{v}} / F_{\mathrm{m}}$ indicated a complete recovery in the photosynthetic function [40]. XRF analysis, detecting $\mathrm{Fe} \mathrm{K} \alpha$ at $6.4075 \mathrm{keV}$ (Suppl. Figure 2) indicated an increased signal of Fe upon foliar treatments. In comparison to the leaves of Fe deficient plants (Fig. 7A; Suppl. Fig. 3), partial leaf blade foliar Fe ${ }^{\mathrm{III}}$ citrate treatment induced an accumulation of $\mathrm{Fe}$ in the treated leaf parts where the majority of $\mathrm{Fe}$ was accumulated in the leaf central leaf veins (Fig. 7B, C; Suppl. Figs. 4, 5). Foliar treatment had no effect on the distribution of macroelements such as $\mathrm{K}$ and $\mathrm{S}$ in the plant material (Suppl. Figs. 3, 4 and 5).

Mössbauer spectra of the washed and unwashed leaves were fitted using the probability distribution of quadrupole splitting as earlier the same model was applied for the spectrum of the solution at $\mathrm{pH} 5.5$ at the final stage of photodegradation (Fig. 4). The probability distribution of quadrupole splitting was resolved into a combination of 3 components fitted with Gaussian functions [41] and a model consisting of 3 doublets with fixed different values of quadrupole splitting was applied by varying the rest of the hyperfine parameters as described in [47]. The spectrum of the unwashed leaves (Fig. 4B) was almost identical to the spectrum of the solution after photochemical transformation (Fig. 4A). Therefore, it can be concluded that the signal observed was coming mostly from the dried solution left on the surface of the leaf.

For this reason, further Mössbauer studies of the leaves were carried out after careful washing of the samples in $0.1 \%$ Nonit and deionized water. In contrast to the spectrum of the unwashed leaves, the spectrum of the washed leaves (Fig. 4C) exhibited some differences from that of the solution. The change in the ratio of areas and linewidths of components 1 and 2 compared to previous spectra and the visible appearance of a new component 3 suggested that incorporation and biotransformation of the applied ${ }^{57} \mathrm{Fe}$ solution took place. Component 1 with the lowest value of quadrupole splitting (Table 1) corresponds to ferric ions in octahedral oxygen coordination. Since the relative area of this component increased compared to the spectrum of the solution after the photodegradation, it may represent $\mathrm{Fe}^{\mathrm{III}}$ carboxylate complexes which are expected to be major complexed form of Fe suitable for multiple cell functions. Due to the similarity of the hyperfine parameters of $\mathrm{Fe}^{\mathrm{III}}$ citrate and malate, which are expected to be present in the plant tissues, 

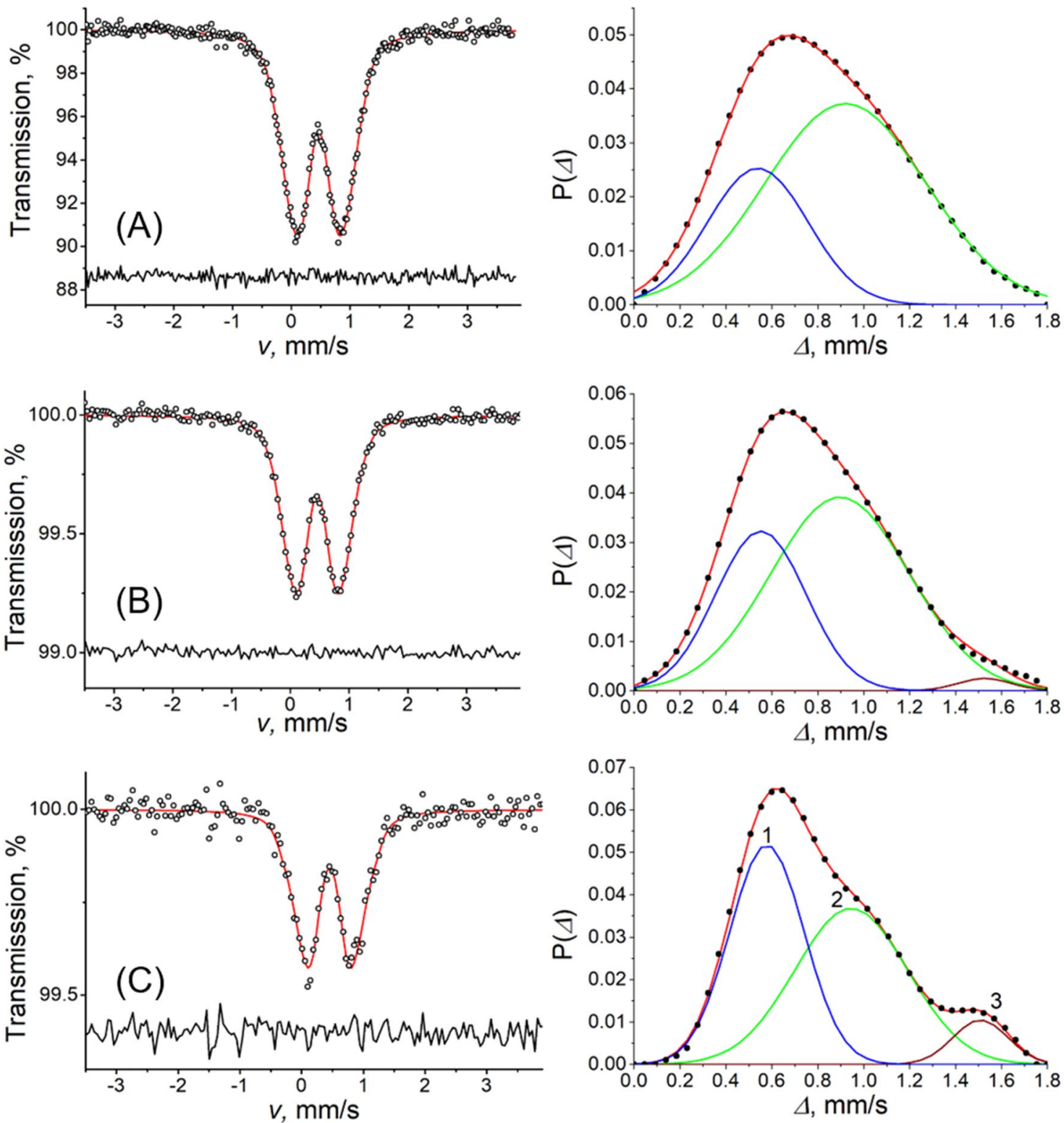

Fig. 4 Mössbauer spectra and the corresponding quadrupole splitting distributions of the frozen solution iron(III)-citrate sample at pH5.5 after $32 \mathrm{~h}$ of light irradiation (A), leaves after foliar treatment $(\mathbf{B})$, washed leaves after foliar treatment $(\mathbf{C})$

this component cannot be further resolved. Component 2 had large linewidth and a center value of quadrupole splitting $\Delta=0.95 \pm 0.02 \mathrm{~mm} / \mathrm{s}$ showing a slight increase compared to the center value of the quadrupole splitting obtained for the spectrum of the solution $\left(\Delta_{\text {cent }}=0.89 \pm 0.02 \mathrm{~mm} / \mathrm{s}\right)$. On the basis of the Mössbauer parameters, iron-sulfur clusters, $\mathrm{Fe}_{4} \mathrm{~S}_{4}$ with a mixed-valent $\mathrm{Fe}^{2.5+}-\mathrm{Fe}^{2.5+}$ center, which normally have a quadrupole splitting around $1 \mathrm{~mm} / \mathrm{s}[11,34,48]$ may be assumed. $\mathrm{Fe}_{4} \mathrm{~S}_{4}$ clusters have a special abundance in the foliage of plants due to the multiple $\mathrm{Fe}_{4} \mathrm{~S}_{4}$ clusters in the photosystem I complexes. The component with the highest value of quadrupole splitting had the parameters, which are almost identical to the dimeric complex of $\mathrm{Fe}^{\mathrm{III}}$ nicotianamine [12]. No components corresponding to $\mathrm{Fe}^{\mathrm{II}}$ complexes were observed.

\section{Discussion}

Upon exposure of the iron(III) + citric acid solution to light, photoreduction of the $\mathrm{Fe}^{\mathrm{III}}$ was observed at all investigated $\mathrm{pH}$ values. $\mathrm{Fe}^{\mathrm{II}}$-organic ligand complexes with the same Mössbauer parameters were formed in all cases, while in the solution prepared at low $\mathrm{pH}$ additional $\mathrm{Fe}^{\mathrm{II}}$ hexaaqua 

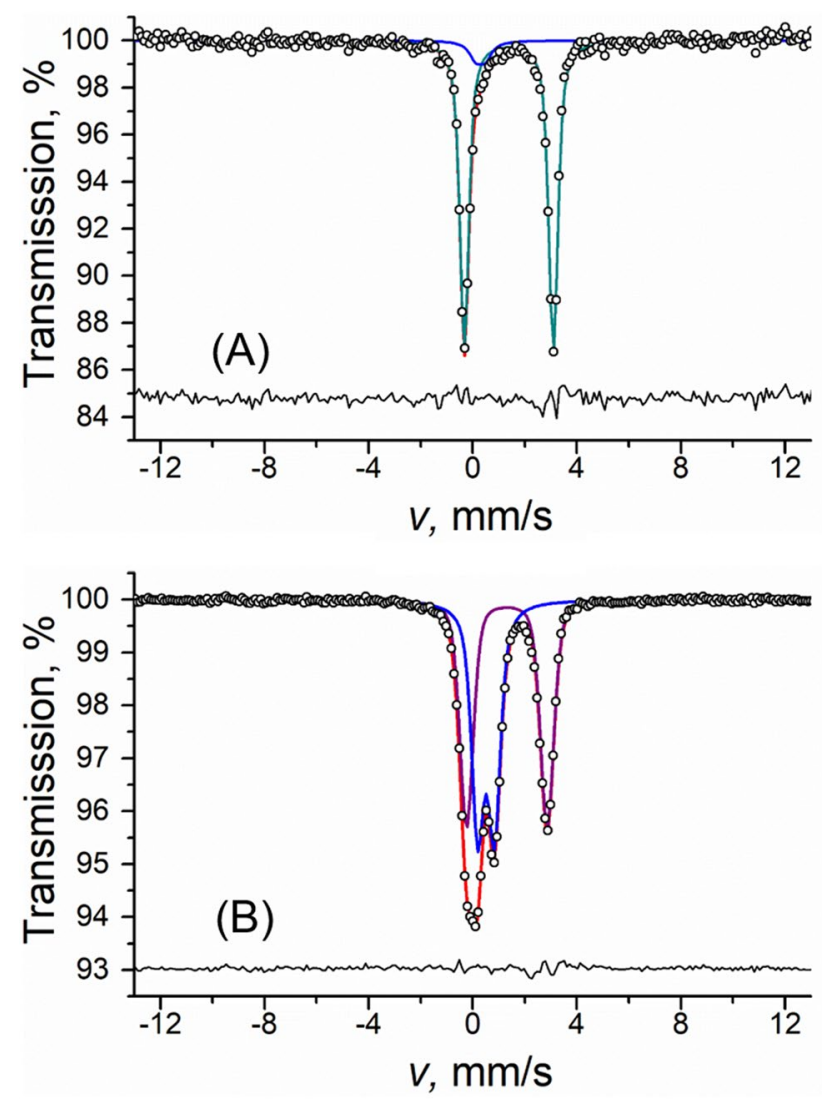

Fig. 5 Mössbauer spectra of the frozen iron(II) + citric acid solutions as-prepared from ${ }^{57} \mathrm{FeSO}_{4}$ at $\mathrm{pH} 1.0(\mathbf{A})$ and after rising $\mathrm{pH}$ to $6(\mathbf{B})$

complex was observed after irradiation. According to HPLC data [18], the organic compounds formed during the decarboxylation of citrate are acetonedicarboxylic, acetoacetic and acetic acids, which may not coordinate to the resulting $\mathrm{Fe}^{\mathrm{II}}$. Taking into account the stoichiometry of the reaction (1) and the applied 1:1.1 Fe to citric acid molar ratio, it can be seen that after total iron photoreduction somewhat more than half of citric acid remained untouched and, thus, it could easily form a new ferrous citrate complex. The results presented in previous works devoted specifically to investigation of $\mathrm{Fe}^{\mathrm{II}}$ coordination during photodegradation of carboxylic acids suggest the formation of various $\mathrm{Fe}^{\mathrm{II}}$ species. Results of laser flash photolysis described in $[49,50]$ reported the formation of long-lived radical complexes with lifetimes in the order of only a millisecond, followed by the dissociation to the organic radical and an $\mathrm{Fe}^{\mathrm{II}}$ aqua complex. In the meantime, calculations performed by Ghoul et al. [14] showed simultaneous presence of $\mathrm{Fe}^{\mathrm{II}}$ aqua and $\mathrm{Fe}^{\mathrm{II}}$ citrato complexes, while the ratio depends on the $\mathrm{pH}$ of the solution. In our case, the observed similarity of Mössbauer parameters of the new $\mathrm{Fe}^{\mathrm{II}}$ compound and the synthesized Fe ${ }^{\mathrm{II}}$ citrate confirmed the formation of the ferrous citrate complex as the only product of photoreduction at $\mathrm{pH}>3$. The presence of a stable complex

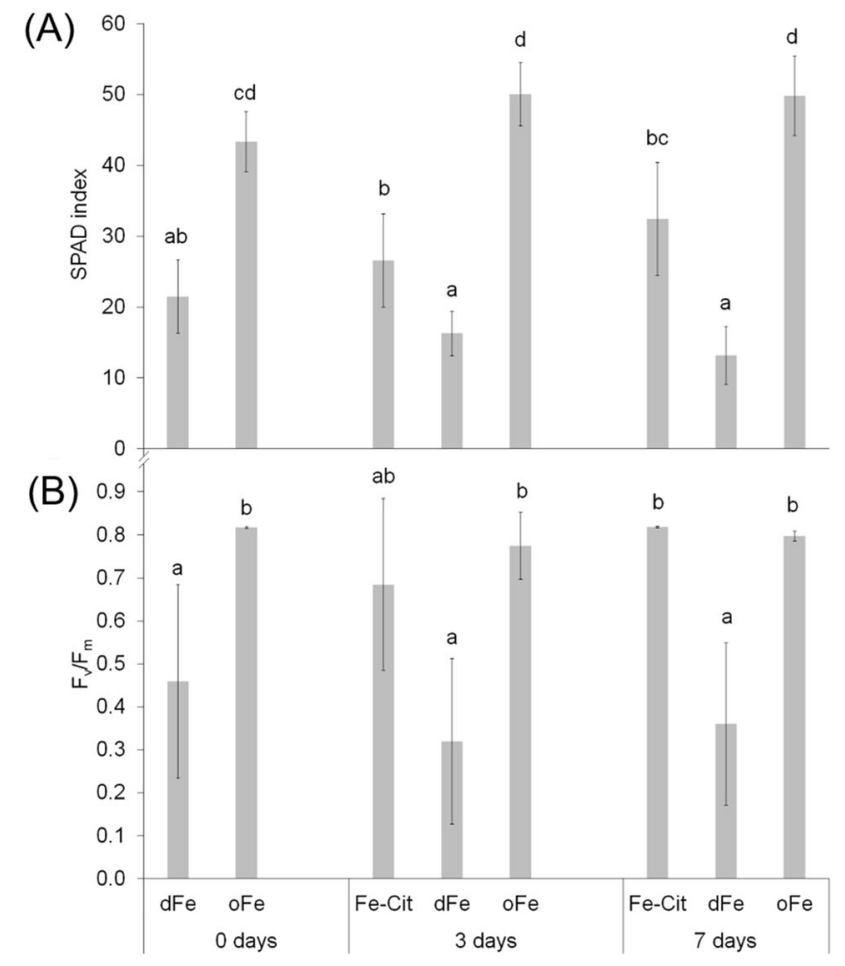

Fig. 6 Changes in the SPAD index (A) corresponding to the chlorophyll content and maximal quantum efficiency of photosystem II reaction centers $\left(F_{\mathrm{v}} / F_{\mathrm{m}}\right)(\mathbf{B})$ during the time of treatment in iron deficient $(\mathrm{dFe})$, iron sufficient $(\mathrm{oFe})$ and iron(III) citrate-treated (Fe-Cit) leaves. Means (columns) and standard deviations (error bars) are presented $(n=5$ [biological $\times$ technical]). Letters denote groups formed based on statistically significant differences $(P<0.01)$ according to one-way ANOVA and Tukey-Kramer post hoc tests on the treatments

between $\mathrm{Fe}^{\mathrm{II}}$ and organic radical at all $\mathrm{pH}$ values is in a good agreement with the calculations [14], small variation in the region of low $\mathrm{pH}$ is probably caused by different $\mathrm{Fe}$ to citrate molar ratio and final Fe concentration. The inconsistency with the results obtained by laser flash photolysis $[49,50]$ may be caused by the intensity of the laser overcoming the intensity of the lamps used in the plant growth chambers. Mössbauer spectroscopy was applied earlier to study Fe $\mathrm{F}^{\mathrm{III}}$ citrate degradation due to thermal treatment [51], electron [52] and light irradiation [53] but exclusively for crystalline powder samples. It is remarkable that the observed hyperfine parameters for $\mathrm{Fe}^{\mathrm{II}}$ citrate in aqueous solution were different from those reported for crystalline ferrous citrate complexes obtained after electron beam irradiation ( $\Delta=3.38 \pm 0.05 \mathrm{~mm} / \mathrm{s}$ in [52]). The quadrupole splitting of the newly formed $\mathrm{Fe}^{\mathrm{II}}$ organic component was closer to that of the neutral ferrous citrate polymer $\left[\mathrm{Fe}\left(\mathrm{H}_{2} \mathrm{cit}\right)\left(\mathrm{H}_{2} \mathrm{O}\right)\right]_{\mathrm{n}}$ synthesized by Birsa Čelič et al. [54]. Due to the stoichiometry of the reaction (1), it is reasonable that at $\mathrm{pH} 1.5$ only half of $\mathrm{Fe}^{\mathrm{II}}$ was coordinated to citrate left after total photodegradation, and the other half formed only hexaaqua complex. This observation also suggests the existence of ferrous citrate 


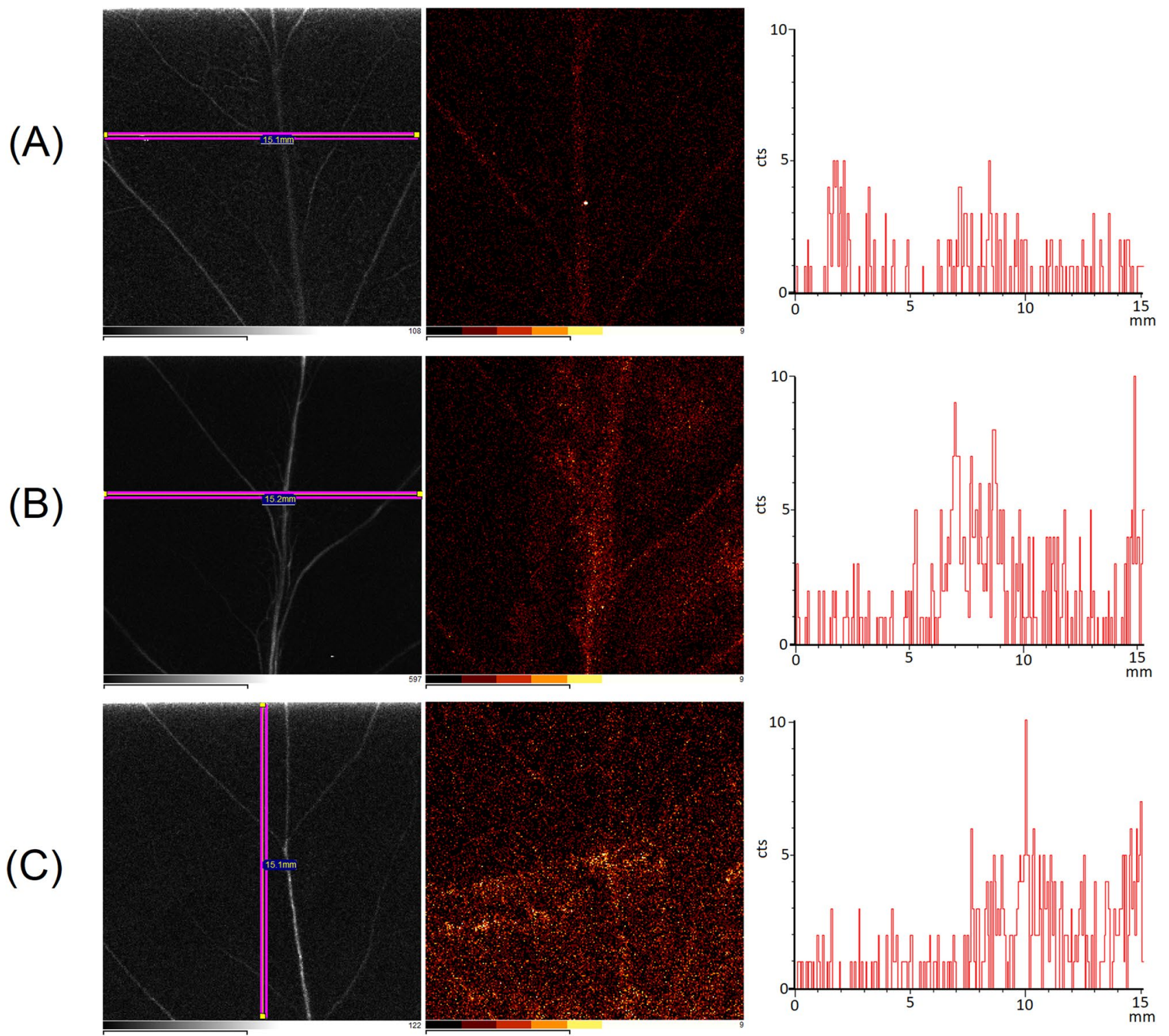

Fig. $7 \mathrm{X}$-ray fluorescence images taken on the total energy-dispersive spectrum (left) and on the Fe K $\alpha$ band (center; also see Suppl. Fig. 2). Distribution of iron in the selected leaf area is shown by horizontal and vertical profiles, respectively, of the leaves (right). Samples were iron deficient leaf (A), leaf subjected to iron(III) citrate treatment on

monoligand complex as was assumed by Timberlake [55] or the formation of a $\mathrm{Fe}^{\mathrm{II}}$ citrate polymer with a structure close to that suggested by Birsa Čelič et al. [54]. Indeed, the

Table 1 Mössbauer parameters obtained from the fitting of the spectrum of the washed leaves

\begin{tabular}{llll}
\hline & $\delta, \mathrm{mm} / \mathrm{s}$ & $\Delta, \mathrm{mm} / \mathrm{s}$ & Relative area, \% \\
\hline Component 1 & $0.45 \pm 0.02$ & $0.58 \pm 0.02$ & $45 \pm 5$ \\
Component 2 & $0.44 \pm 0.02$ & $0.95 \pm 0.02$ & $49 \pm 5$ \\
Component 3 & $0.45 \pm 0.02$ & $1.50 \pm 0.02$ & $6 \pm 2$ \\
\hline
\end{tabular}

the right side of the leaf blade (B) and leaf subjected to iron(III) citrate treatment on the bottom side of the leaf blade $(\mathbf{C})$. Positions of the horizontal/vertical profiles on the mapping area are indicated by purple lines. Scale bar indicates $7 \mathrm{~mm}$ distance

chelating citrate ion is not strong enough to form a complex stable at $\mathrm{pH}>3$ in the presence of oxidants $\left(\mathrm{O}_{2}{ }^{-}, \mathrm{HO}_{2}\right.$ or $\mathrm{H}_{2} \mathrm{O}_{2}$ ). As the $\mathrm{pH}$ of the solution increases, the ferrous ions undergo oxidation to ferric state more easily. If at $\mathrm{pH} 1.5$, one assumes that due to the $1: 1$ metal to ligand ratio, the neutral polymer [54] is the stable formation, then raising the $\mathrm{pH}$ will result in negatively charged chains (deprotonation of the carboxyl groups of citrate) and the internal Coulomb repulsion is expected to decay the chains into monomeric species which must be more vulnerable to oxidation. 
The process of reoxidation was followed by hydrolysis leading to a formation of red polynuclear compounds. The nature of such compounds has been a subject of a great number of studies and the general formula of $\mathrm{Fe}_{3} \mathrm{O}_{\mathrm{r}}(\mathrm{OH})_{\mathrm{s}}{ }^{9-(2 \mathrm{r}+\mathrm{s})}$ was proposed [44]. The observed quadrupole splitting distribution represents a continuum of doublets arising from slightly differing geometrical sites in the polymeric material $[46,47]$. The polynuclear compound is poorly crystallized and photochemically stable. Moreover, some fraction of $\mathrm{Fe}^{\mathrm{III}}$ precipitated in the form of hydroxides as it was earlier observed in [18]. Thus, the fraction of iron suitable for photoreduction decreased. It is remarkable that the hydrolysis cannot be observed in the spectrophotometric measurements because all $\mathrm{Fe}^{\mathrm{II}}$ is complexed by BPDS or other agent. Faster reoxidation was observed at higher $\mathrm{pH}$ in the irradiation time dependence experiments. However, the result contradicts suggestions of Feng et al. [24] that at $\mathrm{pH}>4$ concentration of $\mathrm{Fe}^{\mathrm{II}}$ is negligible due to its rapid oxidation and precipitation in the absence of significant excess of coordinating ligand. In our experiments, at $\mathrm{pH} 1.5$, no oxidation and polymerization of the $\mathrm{Fe}^{\mathrm{III}}$ form occurred. In $\mathrm{Fe}^{\mathrm{III}}$ polymer chains formed during hydrolysis, $\mathrm{Fe}$ atoms were coupled by $\mathrm{Fe}-\mathrm{O}-\mathrm{Fe}$ and $\mathrm{Fe}-\mathrm{OH}-\mathrm{Fe}$ bridges [46]. At low $\mathrm{pH}$, these oxygens got protonated and the bridge was destroyed leaving iron photochemically active and leading to the total photoreduction when citric acid, as oxidizable agent was present.

Mössbauer analysis of the leaves treated with $\mathrm{Fe}^{\mathrm{III}}$ citrate revealed the similarity of the spectra obtained on unwashed leaves and on the photodegraded solution. The results suggest that a significant amount of the solution remained on the surface of the leaves long enough to undergo photodegradation. Since the entry through the cuticle-even at the application of surfactants-is a low probability process [56], Fe compounds on the surface were subjects of photochemical excitation. Thus, the measured transformation of Fe species arose not because of a biological origin but rather by a photochemical effect. Therefore, the final state of the surface solution was almost identical to the state observed in the in vitro solution experiment. Differences between the spectra of washed and unwashed leaves indicated that the applied 1 -week period was enough for a certain amount of ${ }^{57} \mathrm{Fe}$ nuclei to be transformed and incorporated into the biological structures, also shown by the accumulation of Fe nuclei especially in the leaf veins of the treated area. Since chloroplasts have the highest demand for $\mathrm{Fe}$ in the photosynthetic tissues [10, 57, 58], foliar Fe treatment can finally lead to the incorporation of Fe into the plastids. This is supported by the presence of iron-sulfur clusters observed, most probably linked with the photosynthetic apparatus. The presence of $\mathrm{Fe}^{\mathrm{III}}$ carboxylates in the washed leaf material can be linked both with xylem iron transport, iron storage in vacuoles [39] and, as a minor component, cytoplasm labile iron pool. $\mathrm{Fe}^{\mathrm{III}}$ nicotianamine is expected to be the main iron compound in the phloem-based and other symplastic iron transport routes [59]. It is also suggested that $\mathrm{Fe}^{\mathrm{III}}$ nicotianamine complexes are generally involved in $\mathrm{Fe}$ re-distribution processes and Fe translocation from treated leaves to untreated ones [60].

Taking into account the biological relevance, the photoreduction of $\mathrm{Fe}^{\mathrm{III}}$ citrate complexes is significant under constant irradiation. $\mathrm{Fe}^{\mathrm{II}}$-species resulting from these processes can be substrates of ferrous iron membrane transport processes, thus $\mathrm{Fe}$ photoreduction can support the reduction based iron transport in plants. Therefore, ferric citrate photodegradation and iron photoreduction can be a significant component in bypassing biological reduction of $\mathrm{Fe}^{\mathrm{III}}$ citrate.

\section{Conclusions}

The photochemical properties of $\mathrm{Fe}^{\mathrm{III}}$ citrate complexes highly depend on the $\mathrm{pH}$, ligand-to-metal ratio and light exposure conditions. Thus, its photochemical transformation should be taken into account in plant biology/agronomy (e.g., foliar treatment of plants, modeling microbial systems). For this reason, a detailed Mössbauer spectroscopy study of $\mathrm{Fe}^{\mathrm{III}}$ citrate system was carried out under biologically relevant conditions. According to our results, the conclusions are as follows:

- Complete photoreduction of $\mathrm{Fe}^{\mathrm{III}}$ citrate occurred only at very low $\mathrm{pH}$, while at $\mathrm{pH}>3(3.3,5.5$ and 7.0$)$, a subsequent reoxidation of $\mathrm{Fe}^{\mathrm{II}}$ was detected, resulting, presumably, in the partial hydrolysis and polymerization of $\mathrm{Fe}^{\mathrm{III}}$ into a photochemically stable compound.

- The formation of $\mathrm{Fe}^{\mathrm{II}}$ citrate was observed at all investigated $\mathrm{pH}$ values. Under highly acidic conditions, all $\mathrm{Fe}^{\mathrm{III}}$ was photoreduced into a stable mixture of $\mathrm{Fe}^{\mathrm{II}}$ hexaaqua and citrate complexes. The ratio between $\mathrm{Fe}^{\mathrm{II}}$ and the citrate still available after its photochemical degradation allows us to assume the existence of monoligand $\mathrm{Fe}^{\mathrm{II}}$ citrate complex.

- The iron species detected in the unwashed leaves were identical to those observed in the solution exposed to the same illumination conditions indicating that processes on the leaf surface can be modeled by the processes in the iron-containing solutions. The dominant iron species found in the washed leaves indicate that the majority of iron nuclei taken up by the foliage of iron-deficient plants are allocated to the chloroplasts, to symplastic iron transport routes and most probably to vacuolar storage.

Supplementary Information The online version contains supplementary material available at https://doi.org/10.1007/s43630-022-00188-1. 
Funding Open access funding provided by Eötvös Loránd University. This work was supported by the grant financed by the National Research, Development and Innovation Office, Hungary (NKFIH K-124159). Investigations were carried out in the frame of ELTE Thematic Excellence Program 2020 Supported by National Research, Development and Innovation Office-TKP2020-IKA-05. The work was also supported by the European Structural and Investment Fund, grant no. VEKOP-2.3.3-15-2016-00008.

\section{Declarations}

Conflict of interest The authors have no conflicts of interest or competing interests to declare.

Open Access This article is licensed under a Creative Commons Attribution 4.0 International License, which permits use, sharing, adaptation, distribution and reproduction in any medium or format, as long as you give appropriate credit to the original author(s) and the source, provide a link to the Creative Commons licence, and indicate if changes were made. The images or other third party material in this article are included in the article's Creative Commons licence, unless indicated otherwise in a credit line to the material. If material is not included in the article's Creative Commons licence and your intended use is not permitted by statutory regulation or exceeds the permitted use, you will need to obtain permission directly from the copyright holder. To view a copy of this licence, visit http://creativecommons.org/licenses/by/4.0/.

\section{References}

1. Vigani, G., \& Murgia, I. (2018). Iron-requiring enzymes in the spotlight of oxygen. Trends in plant science, 23(10), 874-882. https://doi.org/10.1016/j.tplants.2018.07.005

2. Galaris, D., Barbouti, A., \& Pantopoulos, K. (2019). Iron homeostasis and oxidative stress: An intimate relationship. Biochimica et Biophysica Acta (BBA)-Molecular Cell Research, 1866(12), 118535. https://doi.org/10.1016/j.bbamcr.2019.118535

3. Lv, G., Du, C., Ma, F., Shen, Y., \& Zhou, J. (2020). In situ detection of rice leaf cuticle responses to nitrogen supplies by depthprofiling Fourier transform photoacoustic spectroscopy. Spectrochimica Acta Part A: Molecular and Biomolecular Spectroscopy, 228, 117759. https://doi.org/10.1016/j.saa.2019.117759

4. Ram, H., Rashid, A., Zhang, W., Duarte, A. Á., Phattarakul, N., et al. (2016). Biofortification of wheat, rice and common bean by applying foliar zinc fertilizer along with pesticides in seven countries. Plant and Soil, 403(1), 389-401. https://doi.org/10. 1007/s11104-016-2815-3

5. Sharma, S., Malhotra, H., Borah, P., Meena, M. K., Bindraban, P., et al. (2019). Foliar application of organic and inorganic iron formulation induces differential detoxification response to improve growth and biofortification in soybean. Plant Physiology Reports, 24(1), 119-128. https://doi.org/10.1007/s40502-018-0412-6

6. Fernandez, V., Orera, I., Abadía, J., \& Abadía, A. (2009). Foliar iron-fertilisation of fruit trees: Present knowledge and future perspectives-A review. The Journal of Horticultural Science \& Biotechnology, 84, 1-6. https://doi.org/10.1080/14620316.2009. 11512470

7. Tiffin, L. O. (1966). Iron translocation I. Plant culture, exudate sampling, iron-citrate analysis. Plant Physiology, 41(3), 510. https://doi.org/10.1104/pp.41.3.510

8. Knutson, M. D. (2019). Non-transferrin-bound iron transporters. Free Radical Biology and Medicine, 133, 101-111. https://doi. org/10.1016/j.freeradbiomed.2018.10.413
9. Kobayashi, T., Nozoye, T., \& Nishizawa, N. K. (2019). Iron transport and its regulation in plants. Free Radical Biology and Medicine, 133, 11-20. https://doi.org/10.1016/j.freeradbiomed.2018. 10.439

10. Vigani, G., Solti, Á., Thomine, S., \& Philippar, K. (2019). Essential and detrimental - an update on intracellular iron trafficking and homeostasis. Plant and Cell Physiology, 60(7), 1420-1439. https://doi.org/10.1093/pcp/pcz091

11. Solti, Á., Kovács, K., Basa, B., Vértes, A., Sárvári, É., \& Fodor, F. (2012). Uptake and incorporation of iron in sugar beet chloroplasts. Plant Physiology and Biochemistry, 52, 91-97. https://doi. org/10.1016/j.plaphy.2011.11.010

12. Müller, B., Kovács, K., Pham, H. D., Kavak, Y., Pechoušek, J., Machala, L., Zbořil, R., Szenthe, K., Abadía, J., Fodor, F., \& Klencsár, Z. (2019). Chloroplasts preferentially take up ferric-citrate over iron-nicotianamine complexes in Brassica napus. Planta, 249(3), 751-763. https://doi.org/10.1007/ s00425-018-3037-0

13. Jeong, J., Cohu, C., Kerkeb, L., Pilon, M., Connolly, E. L., \& Guerinot, M. L. (2008). Chloroplast Fe(III) chelate reductase activity is essential for seedling viability under iron limiting conditions. Proceedings of the National Academy of Sciences, 105(30), 10619-10624. https://doi.org/10.1073/pnas.0708367105

14. Ghoul, I., Debbache, N., Dekkiche, B. A., Seraghni, N., Sehili, T., Marín, Z., Santaballa, J. A., \& Canle, M. (2019). Fe(III)-citrate enhanced sunlight-driven photocatalysis of aqueous carbamazepine. Journal of Photochemistry and Photobiology A: Chemistry, 378, 147-155. https://doi.org/10.1016/j.jphotochem.2019.04.018

15. Dou, J., Alpert, P. A., Corral Arroyo, P., Luo, B., Schneider, F., Xto, J., Huthwelker, T., Borca, C. N., Henzler, K. D., Raabe, J., \& Watts, B. (2021). Photochemical degradation of iron(III)-citrate/ citric acid aerosol quantified with the combination of three complementary experimental techniques and a kinetic process model. Atmospheric Chemistry and Physics Discussions, 21(1), 1-36. https://doi.org/10.5194/acp-21-315-2021

16. Frahn, J. L. (1958). The photochemical decomposition of the citrate-ferric iron complexes: A study of the reaction products by paper ionoporesis. Australian Journal of Chemistry, 11(4), 399-405. https://doi.org/10.1071/CH9580399

17. Abrahamson, H. B., Rezvani, A. B., \& Brushmiller, J. G. (1994). Photochemical and spectroscopic studies of complexes, of iron(III) with citric acid and other carboxylic acids. Inorganica Chimica Acta, 226(1-2), 117-127. https://doi.org/10.1016/00201693(94)04077-X

18. Dodge, C. J., \& Francis, A. J. (2002). Photodegradation of a ternary iron(III)- Uranium(VI)- Citric acid complex. Environmental Science \& Technology, 36(9), 2094-2100. https://doi.org/10. $1021 / \mathrm{es} 011125 \mathrm{~m}$

19. Feng, W., \& Nansheng, D. (2000). Photochemistry of hydrolytic iron(III) species and photoinduced degradation of organic compounds. A minireview. Chemosphere, 41(8), 1137-1147. https:// doi.org/10.1016/S0045-6535(00)00024-2

20. Nansheng, D., Feng, W., Fan, L., \& Mei, X. (1998). Ferric citrate-induced photodegradation of dyes in aqueous solutions. Chemosphere, 36(15), 3101-3112. https://doi.org/10.1016/S00456535(98)00014-9

21. Ou, X., Quan, X., Chen, S., Zhang, F., \& Zhao, Y. (2008). Photocatalytic reaction by $\mathrm{Fe}(\mathrm{III})$-citrate complex and its effect on the photodegradation of atrazine in aqueous solution. Journal of Photochemistry and Photobiology A: Chemistry, 197(2-3), 382-388. https://doi.org/10.1016/j.jphotochem.2008.02.001

22. Weller, C., Horn, S., \& Herrmann, H. (2013). Photolysis of Fe (III) carboxylato complexes: $\mathrm{Fe}(\mathrm{II})$ quantum yields and reaction mechanisms. Journal of Photochemistry and Photobiology A: Chemistry, 268, 24-36. https://doi.org/10.1016/j.jphotochem. 2013.06.022 
23. Chen, Y., Liu, Z., Wang, Z., Xue, M., Zhu, X., \& Tao, T. (2011). Photodegradation of propranolol by Fe(III)-citrate complexes: Kinetics, mechanism and effect of environmental media. Journal of Hazardous Materials, 194, 202-208. https://doi.org/10.1016/j. jhazmat.2011.07.081

24. Feng, X., Wang, Z., Chen, Y., Tao, T., Wu, F., \& Zuo, Y. (2012). Effect of $\mathrm{Fe}(\mathrm{III}) /$ citrate concentrations and ratio on the photoproduction of hydroxyl radicals: Application on the degradation of diphenhydramine. Industrial \& Engineering Chemistry Research, 51(20), 7007-7012. https://doi.org/10.1021/ie300360p

25. Abida, O., Kolar, M., Jirkovsky, J., \& Mailhot, G. (2012). Degradation of 4-chlorophenol in aqueous solution photoinduced by Fe(III)-citrate complex. Photochemical \& Photobiological Sciences, 11(5), 794-802. https://doi.org/10.1039/C2PP05358F

26. Bienfait, H. F., \& Scheffers, M. R. (1992). Some properties of ferric citrate relevant to the iron nutrition of plants. Plant and Soil, 143(1), 141-144. https://doi.org/10.1007/BF00009139

27. Bennett, J. H., Lee, E. H., Krizek, D. T., Olsen, R. A., \& Brown, J. C. (1982). Photochemical reduction of iron. II. Plant related factors. Journal of Plant Nutrition, 5(4-7), 335-344. https://doi. org/10.1080/01904168209362962

28. Merkel, D. G., Tanczikó, F., Sajti, S., Major, M., Németh, A., Bottyán, L., Horváth, Z. E., Waizinger, J., Stankov, S., \& Kovács, A. (2008). Modification of local order in FePd films by low energy $\mathrm{He}^{+}$irradiation. Journal of Applied Physics, 104(1), 013901. https://doi.org/10.1063/1.2938027

29. Merkel, D. G., Lengyel, A., Nagy, D. L., Németh, A., Horváth, Z. E., et al. (2020). Reversible control of magnetism in FeRh thin films. Scientific Reports, 10(1), 1-11. https://doi.org/10.1038/ s41598-020-70899-x

30. Vértes, A., \& Nagy, D. L. (1990). Mössbauer spectroscopy of frozen solutions. Akadémiai Kiadó.

31. Kamnev, A. A., Tugarova, A. V., Shchelochkov, A. G., Kovács, K., \& Kuzmann, E. (2020). Diffuse reflectance infrared Fourier transform (DRIFT) and Mössbauer spectroscopic study of Azospirillum brasilense Sp7: Evidence for intracellular iron(II) oxidation in bacterial biomass upon lyophilisation. Spectrochimica Acta Part A: Molecular and Biomolecular Spectroscopy, 229, 117970. https://doi.org/10.1016/j.saa.2019.117970

32. Kamnev, A. A., Perfiliev, Y. D., Kulikov, L. A., Tugarova, A. V., Kovács, K., Homonnay, Z., \& Kuzmann, E. (2017). Cobalt(II) complexation with small biomolecules as studied by ${ }^{57} \mathrm{Co}$ emission Mössbauer spectroscopy. Spectrochimica Acta Part A: Molecular and Biomolecular Spectroscopy, 172, 77-82. https:// doi.org/10.1016/j.saa.2016.04.031

33. Kamnev, A. A., \& Tugarova, A. V. (2021). Bioanalytical applications of Mössbauer spectroscopy. Russian Chemical Reviews, 90(11), 1415. https://doi.org/10.1070/RCR5006

34. Kamnev, A. A., \& Tugarova, A. V. (2017). Sample treatment in Mössbauer spectroscopy for protein-related analyses: Nondestructive possibilities to look inside metal-containing biosystems. Talanta, 174, 819-837. https://doi.org/10.1016/j.talanta.2017.06.057

35. Kamnev, A. A., Kovács, K., Alenkina, I. V., \& Oshtrakh, M. I. (2013). Mössbauer spectroscopy in biological and biomedical research. In Mössbauer Spectroscopy: Applications in Chemistry, Biology, and Nanotechnology (pp. 272-291). Wiley-Blackwell

36. Silva, A. M., Kong, X., Parkin, M. C., Cammack, R., \& Hider, R. C. (2009). Iron(III) citrate speciation in aqueous solution. Dalton Transactions, 40, 8616-8625. https://doi.org/10.1039/B910970F

37. Field, T. B., McCourt, J. L., \& McBryde, W. A. E. (1974). Composition and stability of iron and copper citrate complexes in aqueous solution. Canadian Journal of Chemistry, 52(17), 3119-3124. https://doi.org/10.1139/v74-458

38. Warner, R. C., \& Weber, I. (1953). The cupric and ferric citrate complexes. Journal of the American Chemical Society, 75(20), 5086-5094. https://doi.org/10.1021/ja01116a055
39. Rellán-Álvarez, R., Giner-Martínez-Sierra, J., Orduna, J., Orera, I., Rodríguez-Castrillón, J. Á., García-Alonso, J. I., Abadía, J., \& Álvarez-Fernández, A. (2010). Identification of a tri-iron(III), tri-citrate complex in the xylem sap of iron-deficient tomato resupplied with iron: New insights into plant iron long-distance transport. Plant and Cell Physiology, 51(1), 91-102. https://doi. org/10.1093/pcp/pcp170

40. Torres, R., Diz, V. E., \& Lagorio, M. G. (2018). Effects of gold nanoparticles on the photophysical and photosynthetic parameters of leaves and chloroplasts. Photochemical \& Photobiological Sciences, 17(4), 505-516. https://doi.org/10.1039/C8PP00067K

41. Klencsár, Z., Kuzmann, E., \& Vértes, A. (1996). User-friendly software for Mössbauer spectrum analysis. Journal of Radioanalytical and Nuclear Chemistry, 210(1), 105-118. https://doi.org/ $10.1007 / \mathrm{bf02055410}$

42. Platchinda, A., Ranogajec-Komor, M., \& Vértes, A. (1972). Mössbauer study of quenched Fe(III) salt solutions. Journal of Radioanalytical and Nuclear Chemistry, 10(1), 89-94. https://doi.org/ 10.1007/bf02518770

43. Epstein, L. M., Cheng, H. S., Lin, C. I., \& Li, N. C. (1970). The Mössbauer spectra of iron(III)-citrate complexes. Journal of Inorganic and Nuclear Chemistry, 32(6), 2104-2106. https://doi.org/ 10.1016/0022-1902(70)80622-4

44. Johnston, J. H., \& Lewis, D. G. (1986). A study of the initiallyformed hydrolysis species and intermediate polymers and their role in determining the product iron oxides formed in the weathering of iron. In: Industrial applications of the Mössbauer effect (pp. 565-583). Springer, https://doi.org/10.1007/978-1-4613-1827-9_ 31

45. Zimbovskaya, M. M., Polyakov, A. Y., Volkov, D. S., Kulikova, N. A., et al. (2020). Foliar application of humic-stabilized nanoferrihydrite resulted in an increase in the content of iron in wheat leaves. Agronomy, 10(12), 1891. https://doi.org/10.3390/agron omy10121891

46. Cornell, R. M., \& Schwertmann, U. (2003). The iron oxides: Structure, properties, reactions, occurrences and uses. Wiley.

47. Stolyar, S. V., Kolenchukova, O. A., Boldyreva, A. V., Kudryasheva, N. S., et al. (2021). Biogenic ferrihydrite nanoparticles: Synthesis, properties in vitro and in vivo testing and the concentration effect. Biomedicines, 9(3), 323. https://doi.org/10. 3390/biomedicines 9030323

48. Middleton, P., Dickson, D. P., Johnson, C. E., \& Rush, J. D. (1980). Interpretation of the Mössbauer Spectra of the highpotential iron protein from Chromatium. European journal of biochemistry, 104(1), 289-296. https://doi.org/10.1111/j.14321033.1980.tb04427.x

49. Glebov, E. M., Pozdnyakov, I. P., Grivin, V. P., Plyusnin, V. F., Zhang, X., Wu, F., \& Deng, N. (2011). Intermediates in photochemistry of $\mathrm{Fe}(\mathrm{III})$ complexes with carboxylic acids in aqueous solutions. Photochemical \& Photobiological Sciences, 10(3), 425-430. https://doi.org/10.1039/C0PP00151A

50. Pozdnyakov, I. P., Glebov, E. M., Plyusnin, V. F., Grivin, V. P., Bunduki, E., Goryacheva, N. V., Gladki, V., \& Duka, G. G. (2009). Photochemistry of Fe(III) complex with glyoxalic acid in aqueous solution. High Energy Chemistry, 43, 406-409. https:// doi.org/10.1134/S0018143909050129

51. Bassi, P. S., Randhawa, B. S., \& Jamwal, H. S. (1984). Mössbauer study of the thermal decomposition of iron(III) citrate pentahydrate. Journal of Thermal Analysis and Calorimetry, 29(3), 439-444. https://doi.org/10.1007/bf01913454

52. Baggio-Saitovitch, E., Friedt, J. M., \& Danon, J. (1972). Mössbauer study of irradiated iron chelates and chemical consequences of ${ }^{57} \mathrm{Co}$ electron capture in complex ligand compounds. The Journal of Chemical Physics, 56(3), 1269-1274. https://doi.org/10. 1063/1.1677357 
53. Buchanan, D. N. E. (1970). Mössbauer spectroscopy of radiolytic and photolytic effects on ferric citrate. Journal of Inorganic and Nuclear Chemistry, 32(11), 3531-3533. https://doi.org/10.1016/ 0022-1902(70)80161-0

54. Birsa Čelič, T., Jagličič, Z., Lazar, K., \& Zabukovec Logar, N. (2013). Structure and magnetic properties of a new iron(II) citrate coordination polymer. Acta Crystallographica Section B: Structural Science, Crystal Engineering and Materials, 69(5), 490-495. https://doi.org/10.1107/S2052519213023713

55. Timberlake, C. F. (1964). 975. Iron-malate and iron-citrate complexes. Journal of the Chemical Society (Resumed). https://doi. org/10.1039/JR9640005078

56. Malhotra, H., Pandey, R., Sharma, S., \& Bindraban, P. S. (2020). Foliar fertilization: Possible routes of iron transport from leaf surface to cell organelles. Archives of Agronomy and Soil Science, 66(3), 279-300. https://doi.org/10.1080/03650340.2019.1616288

57. Pham, H. D., Pólya, S., Müller, B., Szenthe, K., Sági-Kazár, M., et al. (2020). The developmental and iron nutritional pattern of PIC1 and NiCo does not support their interdependent and exclusive collaboration in chloroplast iron transport in Brassica napus. Planta, 251(5), 1-16. https://doi.org/10.1007/ s00425-020-03388-0

58. Sági-Kazár, M., Zelenyánszki, H., Müller, B., Cseh, B., Gyuris, B., Farkas, S. Z., et al. (2021). Supraoptimal iron nutrition of Brassica napus plants suppresses the iron uptake of chloroplasts by down-regulating chloroplast ferric chelate reductase. Frontiers in Plant Science, 12, 748. https://doi.org/10.3389/fpls.(2021. 658987

59. Schuler, M., Rellán-Álvarez, R., Fink-Straube, C., Abadía, J., \& Bauer, P. (2012). Nicotianamine functions in the phloem-based transport of iron to sink organs, in pollen development and pollen tube growth in Arabidopsis. The Plant Cell, 24(6), 2380-2400. https://doi.org/10.1105/tpc.112.099077

60. Kumar, R. K., Chu, H. H., Abundis, C., Vasques, K., Rodriguez, D. C., et al. (2017). Iron-nicotianamine transporters are required for proper long distance iron signaling. Plant Physiology, 175(3), 1254-1268. https://doi.org/10.1104/pp.17.00821 